\title{
Predicting fear of being single based on personality types, emotional intelligence, and demographic variables
}

\author{
Mohammad Darba $^{1}$, Somayeh Shahmoradi ${ }^{2}$, Zahra Naghsh ${ }^{2}$, Yaser Madani \\ 1-M.A Student of Family Counseling, Department of Educational Psychology and Counseling, University of \\ Tehran, Tehran, Iran. \\ 2- Assistant Professor, Department of Educational Psychology and Counseling, University of Tehran, Tehran, Iran. \\ Corresponding Author: Somayeh Shahmoradi \\ E-mail: s.shaahmoradii@ut.ac.ir
}

Received: $31 / 08 / 2020$

\begin{abstract}
Introduction: Recent developments in current societies have brought about changes in the age of marriage, so that the number of single people is increasing. These conditions are unpleasant for some people and they experience the fear of being single.

Aim: The aim of this study was to predict the fear of being single based on personality types, emotional intelligence and demographic variables.

Method: The research method was descriptive-correlational studies. The statistical population of the study included all students of the University of Tehran in the academic year of 2019-2020, who were selected by available sampling method and answered online questionnaires by calling online. Demographic questionnaires, fears of being single (2013), Myers-Briggs personality traits (1987), and Bar-on's emotional intelligence (1997) were used to collect data. The data collected were analyzed through SPSS-22 software.

Results: The results showed that there was a significant relationship between personality types, emotional intelligence and demographic variables (age, income and education) with fear of being single $(\mathrm{P}<0.05)$. Moreover, personality types, emotional intelligence and demographic variables were able to predict $28 \%, 16 \%$ and $9 \%$ of the variance of fear of being single, respectively.

Conclusion: The results of the present study can be used to identify variables related to fear of being single in individual and premarital counseling and accordingly used appropriate preventive and interventions methods.
\end{abstract}

Keywords: Fear of being single, Personality types, Emotional intelligence, Demographic variables, Students

How to cite this article : Darba M, Shahmoradi S, Naghsh Z, Madani Y. Predicting fear of being single based on personality types, emotional intelligence, and demographic variables. Shenakht Journal of Psychology and Psychiatry. 2020; 7 (5): 52-64. URL: http://shenakht.muk.ac.ir/article-1-1029-en.pdf

Copyright $\odot 2018$ the Author (s). Published by Kurdistan University of Medical Sciences. This is an open access article distributed under the terms of the Creative Commons Attribution-Non Commercial License 4.0 (CCBY-NC), where it is permissible to download, share, remix, transform, and buildup the work provided it is properly cited. The work cannot be used commercially without permission from the journal. 


\title{
يشيشينى ترس از تجرد بر اساس تيڤهاى شخصيتى، هوش هيجانى و متغير هاى جمعيت شناختى
}

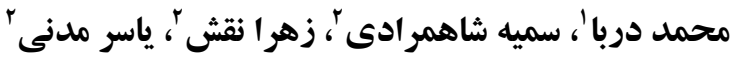

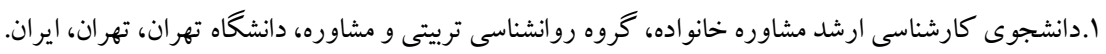

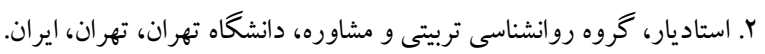 \\ ايميل:s.shaahmoradii@ut.ac.ir \\ مولف مسئول: سميه شاهمر ادى
}

مقدمه: تحولات اخير جوامع كنونى تغييراتى رادر سن ازدواج ايجاد كرده، به طورى كه تعداد مجردها رو به فزونى است. اين شرايط براى برخى از افراد ناخوشايند بوده و ترس از تجرد را تجربه مى كنند.

هدف: يُوهش حاضر با هدف بيشينى ترس از تجرد بر اساس تيبههاى شخصيتى، هوش هيجانى و متغيرهاى جمعيت شناختى انجام كرفت.

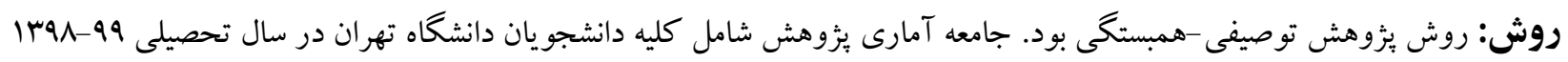

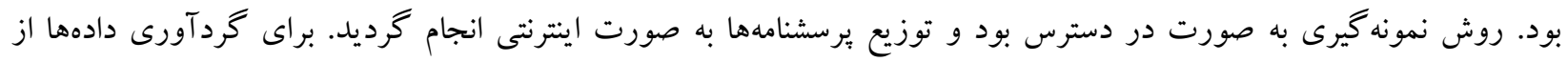

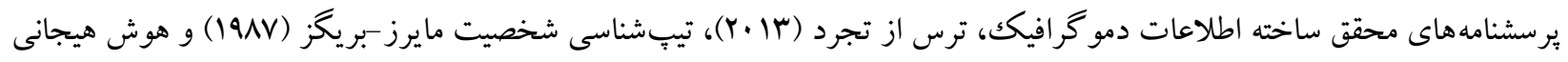

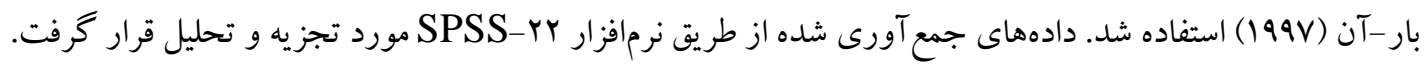

يافتهها: نتايج نشان داد كه بين تيِهاى شخصيتى، هوش هيجانى و متغيرهاى دمو گر افيك (سن، در آمد و مقطع تحصيلى) با ترس از

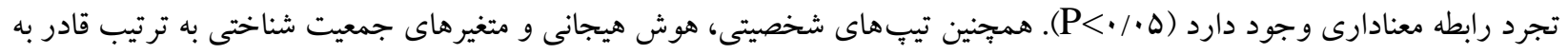
ويشينى 1 Y درصد، 19 درصد و 9 درصد از واريانس ترس از تجرد بودند.

نتيجلكيرى: از نتايج يزوهش حاضر مىتوان در جهت شناخت متغيرهاى مرتبط با ترس از تجرد در مشاورههاى فردى و بيش از

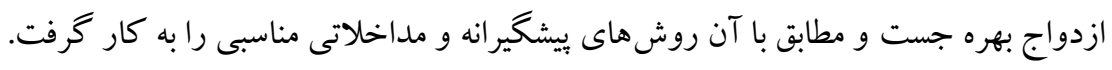
كليدوازهها: ترس از تجرد، تيبّهاى شخصيتى، هوش هيجانى، متغيرهاى جمعيت شناختى، دانشجويان 
تصاوير دلبستگى و بايگاهى امن براى تأمين آسايش

و امنيت روانى برقرار مى كنند. ناكامى در دستيابى به

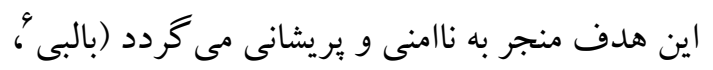

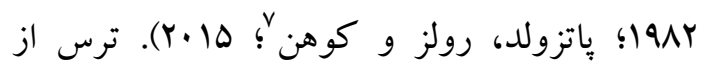
تجرد از عوامل مختلفى تأثير مىيذيرد، ازجمله: سبك هاى دلبستكى، ويز گیى هاى شخصيتى، احساس تنهايى، نياز به تعلق (اسييلمان و همكاران، سا.ب(Y)،

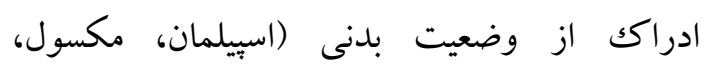

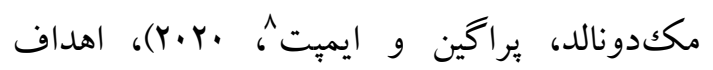

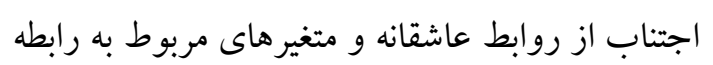

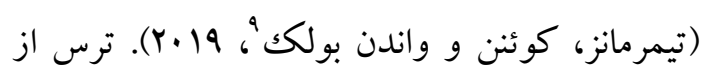

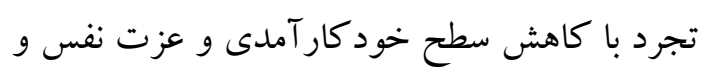
متعاقباً بايين آمدن ملاككهاى انتخاب همسر همراه

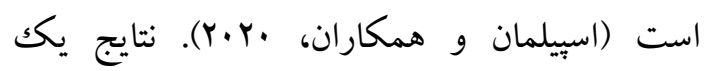
يزوهش كيفى نشان داد كه واكنش افراد به مجرد بودن متفاوت است و براى برخى از افراد احساس

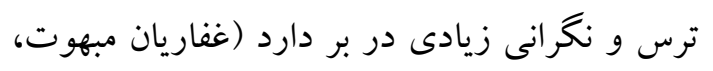
ها ·Y). يكى از نشانهاى اختلاف افراد در ميزان تعلق پِذيرى و ترس از تجرد، نشئت كرفته از

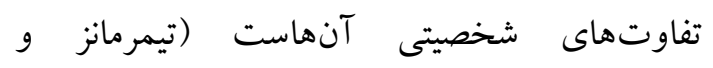

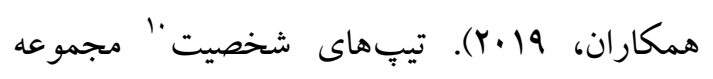
مشخصى از تمايلات رفتارى و صفات نسبتاً بِايدار

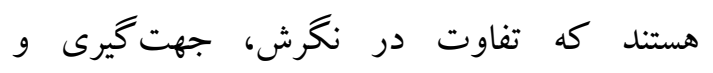
سبك هاى تصميم گيرى افراد را نشان مىدهند و ورتئ نقشى تعيين كننده در بيشينى الكوهاى رفتار و

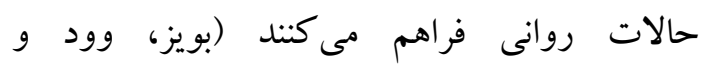

6- Bowlby

7- Paetzold, Rholes \& Kohn

${ }^{8}$ - Spielmann, Maxwell, MacDonald, Peragine \& Impett,

9 - Timmermans, Coenen \& Van den Bulck

${ }^{10}$ - Personality Types
بر اساس ديد كاه تكاملى، نياز ذاتى به تعلق داشتن در بين تمامى انسانها مشتركك است. ايده اساسى اين

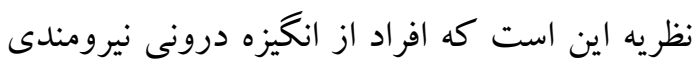
براى ايجاد و حفظ روابط عميق بين فردى برخوردار

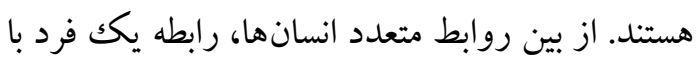
همسر يا شريك زندگىاش مهمترين رابطه بين فردى آنها محسوب مىشود (برشيد و ريگان'، 19.19). روابط عاشقانه از نظر روان شناختى براى

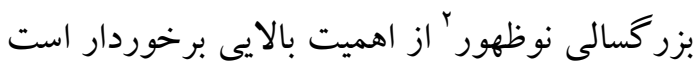

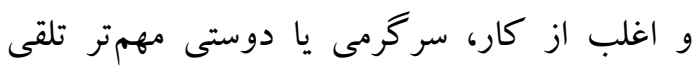

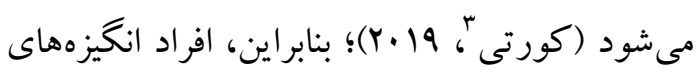
ذاتى و ريشهاى براى دستيابى و حفظ روابط اجتماعى نزديكك دارند. اين انكيزهها منجر به ايجاد نوعى فشار بيولوزيكى و روانشناختى براى برقرارى ييوند عاطفى خواهند شد كه ممكن است در به وجود آمدن ترس از تجردُ نقش داشته باشند

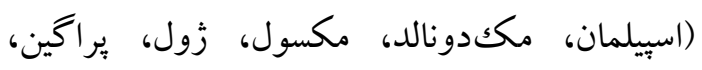

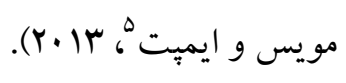

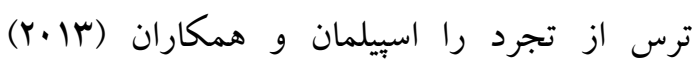
اين گونه تعريف كردهاند: (انكرانى، اضطراب يا يريشانى معطوف به تجربه فعلى يا آينده به دليل نداشتن يكك شريك عاشقانه). بر اساس نظريه دلبستكى نياز به برقرارى بيوندهاى نزديك فراتر از

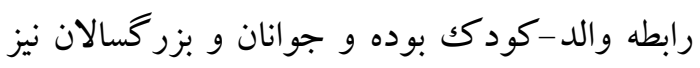

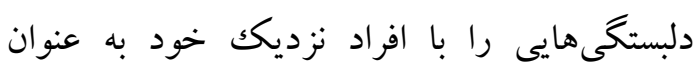

\footnotetext{
${ }^{1}$ - Berscheid \& Regan

2 - Emerging adulthood

3 - Corretti

${ }^{4}$ - Fear of Being Single

5 - Spielmann, MacDonald, Maxwell, Joel, Peragine, Muise \& Impett
} 
عاملى مؤثر و تعيين كننده در برآيندهاى زندگى واقعى مانند مديريت هيجانات و ترسهاى روانشناختى دارد (خدابخش يير كلانى، امانى، رئيسى و حاج كرم، 9941). افراد فاقد هوش هيجانى بالا ممكن است نتوانند روابط عاشقانه موفقيت -

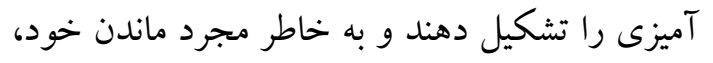

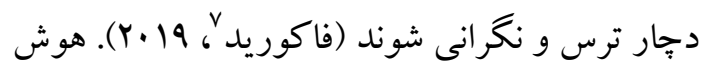
هوش هيجانى در تشخيص ترس از تجرد كمكك كنده بوده و احتمال بروز رفتارهاى تكانشى و تهري ورود به روابط بى كيفيت عاشقانه را كاهش مىدهد

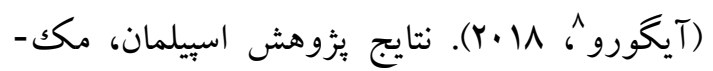

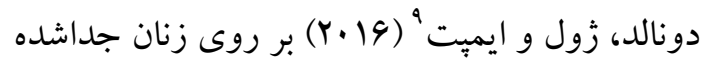
جداشده از همسر نشان داد كه افراد با هوش هيجانى و تو انايى تنظيم هيجانى ضعيف، داراى ترس از تجرد

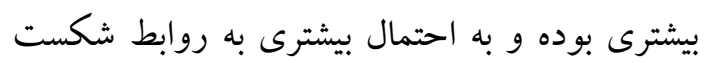
خورده قبلى خود بازمى گر دند. افزون بر نقش عوامل روانى مطرح شده در ايجاد ترس از تجرد، برخى متغيرهاى جمعيت شناختى نيز مىتوانند با ترس از تجرد رابطه داشته باشند. به گونهاى كه برخى از اين متغيرها زمينه ساز

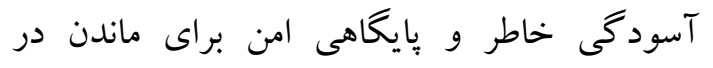
وضعيت تجرد ايجاد مى كند و برخى ديكر سبب

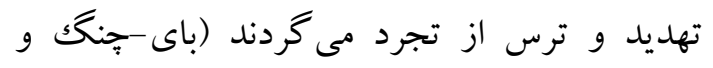

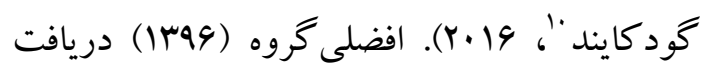
كه بالا رفتن سن با افزايش نغرانى و ترس از تجرد در ارتباط است. نتايج ثروهش شهانواز و اعظم زاده

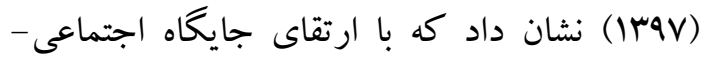

${ }^{7}$ - Fakorede

8 - Aigoro

9 - Spielmann, MacDonald, Joel \& Impett

${ }^{10}$ - Bay-Cheng \& Goodkind
فركوسن'، 19.r). اسييلمان و همكاران (r.1T) دريافند كه برخى ويز خىهاى روانشناختى بايدار ماند صفات شخصيتى مىتواند ترس از تجرد را

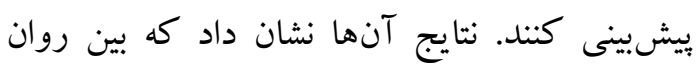
رنجورى با ترس از تجرد رابطه مثبتى برقرار است و برون گرايى، گثودگى به تجربه، وظيفه مدارى و تو افق يذيرى با ترس از تجرد رابطه منفى دارند. دى - لـ

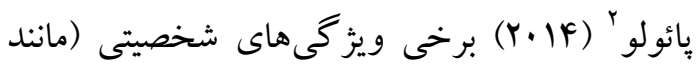

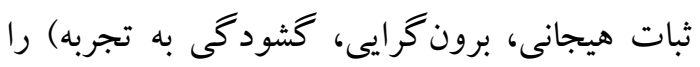
يكى از مزيتهاى اصلى افرادى مىداند كه از مجرد

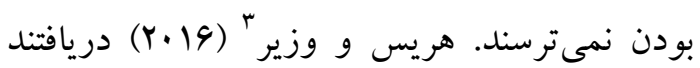
كه برخى تيبهاى شخصيتى نزد ديخران از جذابيت و جاذبه بيشترى برخوردار بوده و يافتن شريك ترك زندگى براى آنها با جالش كمترى همراه است؛ لذا اين افراد نخرانىهاى كمترى از مجرد بودن خود انداه دارند. نتايج بررسىهاى تيمرمانز و همكاران (Y. (Y) نيز نشان داد كه بين تيبهاى شخصيتى احساسى و

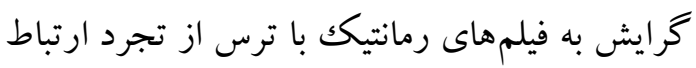
مثبى وجود دارد. عامل ديخرى كه در تشخيص، تعديل و تنظيم ترس از تجرد و مواجهه با آن

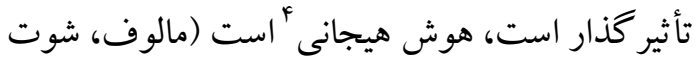

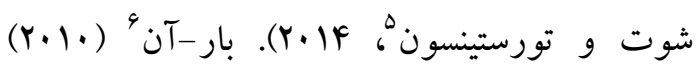
هوش هيجانى را شامل مجموعهاى از مهارتها، استعدادها و توانيىهاى غير شناختى مىداند كه

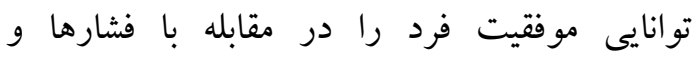
اقتضاهاى محيطى افزايش مىدهد. هوش هيجانى

\footnotetext{
1- Boyce, Wood \& Ferguson

2- DePaulo

3. Harris \& Vazire

${ }^{4}$ - Emotional Intelligence

5 - Malouff, Schutte \& Thorsteinsson,

6- Bar-On
} 
دانشجو بودن در يكى از مقاطع دانشگاه تهران، مجرد بودن و مبتلا نبون به اختلالات روانشناختى؛ ملاككهاى خروج نيز شامل فارغالتحصيل بودن،

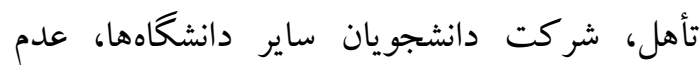
تمايل به شركت در بيزوهش بود. دادههاى

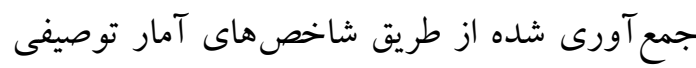
و استنباطى (ضريب همبستخى ويرسون، ركرسيون همزمان) و با استفاده از نسخه r Y نرمافزار SPSS مورد تجزيه و تحليل قرار كرفت. لازم به ذكر است

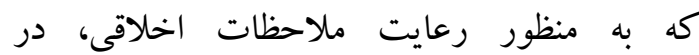

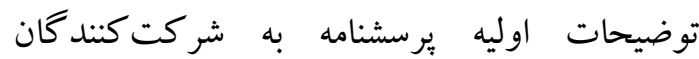
اطمينان خاطر داده شد كه يذيرش برسشنامه بدون نياز به درج نام است و رازدارى و محرمانه بودن اطلاعات لحاظ كرديد.

\section{ابزار}

يرسشنامه اطلاعات جمعيت شناختى: اين يرسشنامه توسط يُزوهشخران جهت سنجش اطلاعات جمعيت شناختى شركت كنند گان از قبيل سن، جنسيت، درآمد و مقطع تحصيلى تهيه و تنظيم شده است. مقياس ترس از تجرد ( FOBSS): توسط اسيّلمان، مككدونالد، مكسول، زول، يراكين، مويس و ايميت (T/.Y) تهيه و تنظيم شده است. داراى V گ Vويه است و در طيف ليكرت ينج درجهاى از كاملاً غلط (1) تا كاملاً درست (ه) (ه) نمرهگذارى مىشود. نمرات بالاتر به معناى ترس بيشتر از مجرد بودن است. بررسى ساختار عاملى تأييدى مقياس ترس از تجرد نشان مىدهد كه اين مقياس ساختارى يكك عاملى دارد. روايى اين مقياس

\footnotetext{
${ }^{2}$ - Fear of Being Single Scale
}

اقتصادى، افراد تمايل دارند تا با ترس و نغخرانى كمترى ازدواج خود را به تعويق بيندازند. نتايج يك يثزوهش نشان داد كه دختران فشارهاى روانى و اجتماعى بيشترى به دليل مجرد بودن خود متحمل شده و نسبت به يسران داراى ترس از تجرد بيشترى

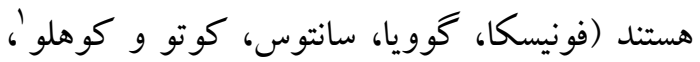
IVIV). با توجه به مبانى نظرى ذكر شده و محدود بودن ادبيات مربوط به سازه ترس از تجرد، درك بهتر اين متغير و عوامل بيشبينى كننده آن، زمينه را براى شناخت و كنترل آن فراهم مى كند؛ بنابراين يثزوهش حاضر در بيى بِاسخگ بريى به اين يرسش است كه آيا تيبهاى شخصيتى، هوش هيجانى و متغيرهاى جمعيت شناختى مىتو انند ترس از تجرد را ييش بينى كنند

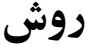
روش يثوهش حاضر توصيفى، از نوع مطالعات

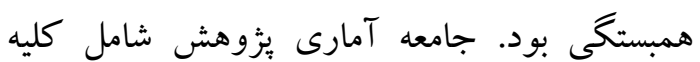
دانشجويان دانشگاه تهران در سال تحصيلى 9919 إ بود. با توجه به حجم جامعه و بر اساس جدول موركان، تعداد هاب نفر به روش نمونه دسترس و داوطلبانه انتخاب و بر اساس ملاككهاى ورود و خروج به يرسشنامههاى آنلاين بِاسخ دادند. بدين ترتيب كه بِ از شناسايى و بررسى كانالها و كروههاى مجازى معتبر دانشكدههاى دانشكاه تهران، لينكك برسشنامه به صورت گسترده در اين فضاها توزيع شد و شركت كنند گان به صورت داوطلبانه وارد صفحه اينترنتى مربوطه شده و يرسشنامهها را تكميل نمودند. ملاككهاى ورود به يزوهش شامل

\footnotetext{
${ }^{1}$ - Fonseca, Gouveia, dos Santos, Couto \& Coelho
} 
نشان از روايى همخراى بالاى اين برسشنامه دارد. اين مقياس در ايران توسط محموديان دهكردى (IMA9) مقياس هاى آن به روش آلفاى كرونباخ براى

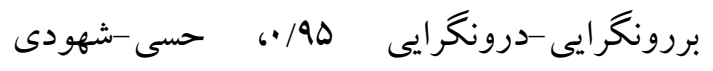

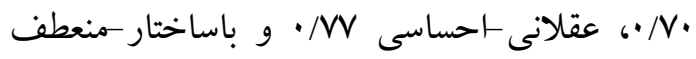
/9F • محاسبه شد. ضريب آلفاى كرونباخ در يثوهش حاضر |N/ • به دست آمد.

مقياس هوش هيجانى بار-آن (Bar-On EQ-ii):

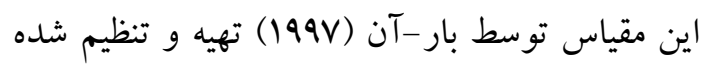
است. نحوه نمره گذارى آن بر روى يك بك مقياس ليكرت هـ درجهاى از كاملاً موافقم (نمره ها ) تا كاملاً مخالفم (نمره 1) است. اين مقياس •و سؤالى مشتمل بر ها خرده مقياس است كه در ها بعد كلى دستهبندى مىشوند: 1- مهارتهاى درون فردى

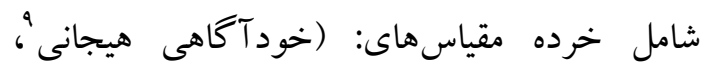

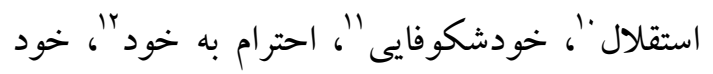

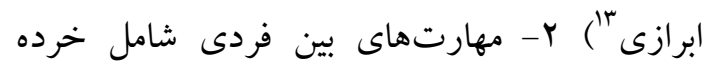

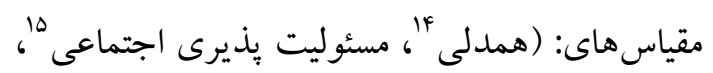

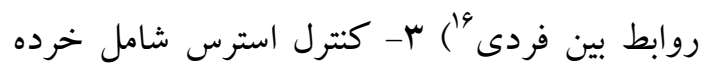

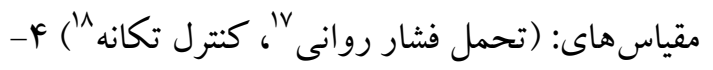
F

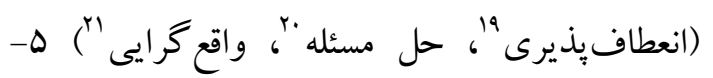

8 - Bar-On Emotional Quotient Inventory

9 - Emotional Self - Awareness

${ }^{10}$ - Independence

${ }^{11}$ - Self-Actualization

12 - Self-Regard

13- Assertiveness

14 - Empathy

15 - Social Responsibity

${ }^{16}$ - Interpersonal Relationship

17 - Stress Tolerance

${ }^{18}$ - Social Responsibility

${ }^{19}$ - Flexibility

${ }^{20}$ - Problem Solving

${ }^{21}$ - Reality Testing
در مطالعات اوليه مطلوب گزارش شده و ميزان

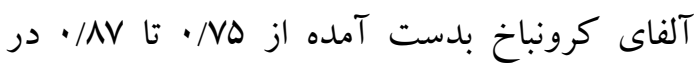

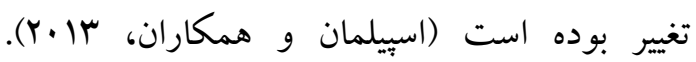
بررسى روايى و يايايى اين برسشنامه توسط فونيسكا

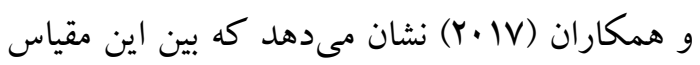
با احساس تنهايى و رضايت از زندگى همبستخى معنادارى وجود دارد كه نشانخر روايى همخراى آن است؛ آلفاى كرونباخ بدست آمده نيز M/ • گزمارش

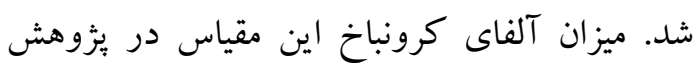
حاضر برابر با ه9/ • به دست آمد.

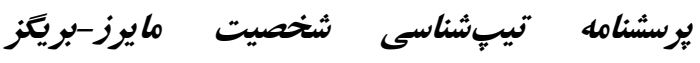
(MBTI') (19AV) شد. اين مقياس داراى فرمهاى مختلفى است كه تيب

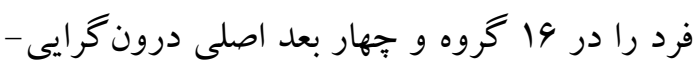

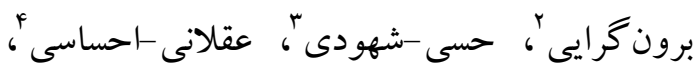
باساختار -منعطفه مشخص ميىسازد و و در اين بثروهش از فرم كوتاه •4 سؤالى آن استفاده شد.

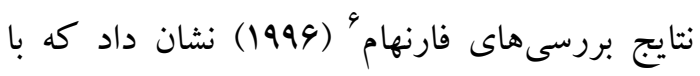
افزايش سن، نمرات تيبٍ هاى شخصيتى از ثبات

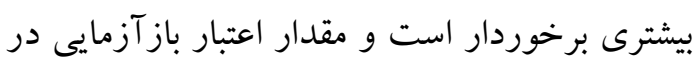
طى يكك دوره دو ماهه از 99/• تا شی/· براى تيبهاى شخصيتى گزارش شد. همجِين بين ابعاد توافق بذيرى، وظيفهشناسى، برونگرايى و تجربه

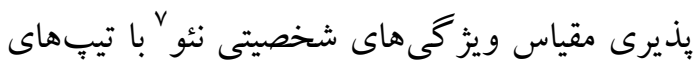

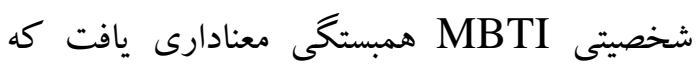

\footnotetext{
1- Myers-Briggs Type Indicator

2- Introversion-Extraversion (I-E)

3 - Sensing-Intuition (S-N)

4- Thinking-Feeling (T-F)

5 - Judgment-Perception (J-P)

6. Furnham

${ }^{7}$ - NEO Personality Inventory
} 


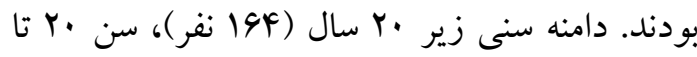

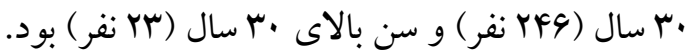
از لحاظ مقطع تحصيلى شركت كنند گان،

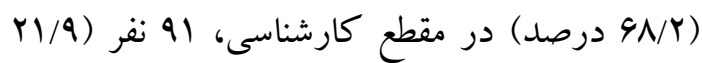
درصد) در مقطع كارشناسى ارشد و أ نفر (9/9 درصد) از شركت كنند گان در مقطع د كترى در حال تحصيل بودند. از لحاظ وضعيت درآمد rOY نفر

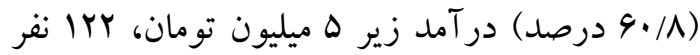

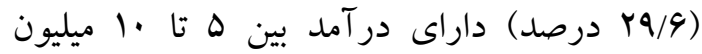
1. تومان و أF نفر (9/V درصد) داراى درآمد بالاى ميليون تومان بودند. در جدول شماره ا آمارههاى توصيفى متغيرهاى مورد مطالعه به همراه ضريب همبستخى بيرسون جهت بررسى رابطه متغيرهاى بيشبين با متغير ملاكك (ترس از تجرد) نشان داده

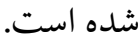

خلق كلى شامل خرده مقياسهاى: (خوشبينى، شادمانى). در اين ابزار براى هر خرده مقياس 9 ماده وجود دارد. بار-آن (•l+Y) در بررسىهاى خود ضريب آلفاى محاسبه شده براى كل مقياس را سه/. و براى خرده مقياسهاى آن بين 99/. تا 941/.

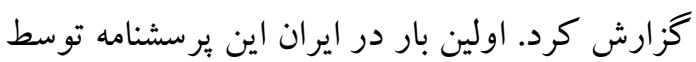
دهشيرى (IMNY) هنجاريابى شد و ضريب پايايى يرسشنامه با استفاده از روش آزمون مجدد بهطور

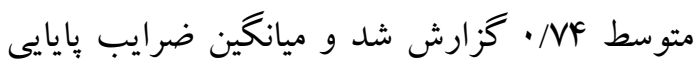

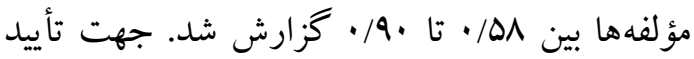
يايايى مقياس مذكور از آلفاى كرونباخ استفاده كرديد كه مقدار آن ضريب لV • بـ به دست آمد.

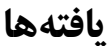

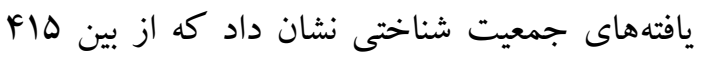
شركت كننده حاضر در يزوهش rDI نفر مؤنث (9./D درصد) و 194 نفر مذكر (q/D درصد)

\section{جدول ا يافتهاى توصيفى و ضرايب همبستكى ييرسون بين متغيرها}

\begin{tabular}{|c|c|c|c|c|c|c|}
\hline $\mathbf{R}$ & كشيدكى & كجى & انحر اف معيار & ميانكين & زير مؤلفه & متغير \\
\hline $1^{* * *}$ & $-\cdot / \Delta F$ & -.1 .9 & $1 r / \cdot 1$ & rN/ $\cdot \mathrm{r}$ & - & ترس از تجرد \\
\hline$\cdot / r b^{* * *}$ & $1 / 11$ & $r / \Gamma \Lambda$ & $9 / Y 1$ & $19 / \Delta F$ & درون كرايى & \multirow[t]{12}{*}{ ويزگى هاى شخصيتى } \\
\hline$-\cdot / \Gamma \Delta^{* * *}$ & $1 / A 1$ & $r / T \wedge$ & $9 / Y)$ & $19 / \Delta F$ & برون كرايیى & \\
\hline$-\cdot / r \cdot * *$ & $-\cdot / v$ & $-\cdot / \cdot r$ & $r / . F$ & $V / T F$ & حسى & \\
\hline$\cdot / r \cdot * *$ & $-\cdot N$ & $-\cdot / \cdot r$ & $r / . F$ & $V / T F$ & شهودى & \\
\hline$-\cdot / r q^{* * *}$ &.$- / 49$ & $-\cdot / 79$ & $r / 19$ & $\Lambda / \cdot V$ & عقلانى & \\
\hline$\cdot / Y q^{* * *}$ &.$- / 49$ & $-\cdot / Y q$ & $r / 19$ & $N / \cdot V$ & احساسى & \\
\hline$\cdot /\left.Y\right|^{* * *}$ & $-\cdot / \wedge 9$ & .1 .4 & $r / \Delta 1$ & $V / 91$ & با ساختار & \\
\hline$-\cdot /\left.Y\right|^{* * *}$ & $-\cdot / 19$ & .1 .4 & $r / \Delta 1$ & $V / 91$ & منعطف & \\
\hline$-\cdot / r \Delta^{* *}$ & $1 / 4$ & $-\cdot 191$ & $19 / 49$ & $1 \cdot \Delta / / F$ & مهارت درون فردى & \\
\hline$\cdot 1 \cdot \Delta$ & $-.1 \cdot 4$ & $-\cdot / Y 4$ & $1 / 99$ & $9 / 11$ & مهارت بين فردى & \\
\hline$-\cdot / \mu r^{* *}$ & $-\cdot / 4$ & $-\cdot / I V$ & $\Lambda / Y)$ & $r 9 / 91$ & كنترل استرس & \\
\hline$-\cdot|\Gamma|^{* * *}$ & $\cdot / \mathrm{W}$ & $-\cdot 149$ & $9 / Y)$ & $\Delta Q / 9 V$ & ساز كارى & \\
\hline
\end{tabular}




\begin{tabular}{|c|c|c|c|c|c|c|}
\hline$-\cdot / r r^{* * * *}$ & $-\cdot / / F$ & $-\cdot / r Y$ & $V / F \Lambda$ & RT/R & خلق كلى & \\
\hline$\cdot / Y F^{* * * *}$ & $1 / 1 \Lambda$ & I/rV & $F / \cdot r$ & $r r / Q$. & - & سن \\
\hline 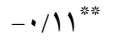 & $F r / Y F$ & $\Delta / \wedge q$ & YF/DY & $f / \Delta \cdots / \cdots$ & - & درآمد \\
\hline
\end{tabular}

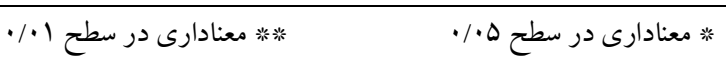

شخصيتى با ترس از تجرد رابطه معنادار وجود دارد

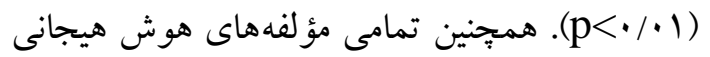

به جز مهارت بين فردى با ترس از تجرد رابطه

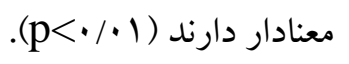

بر اساس دادههاى جدول ا مشخص مىشود كه شاخص كجى و كشيدكى هيج يك از مؤلفه انها

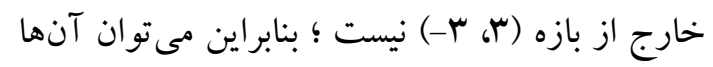
را نرمال يا تقريب نرمال در نظر خرفت. نتايج

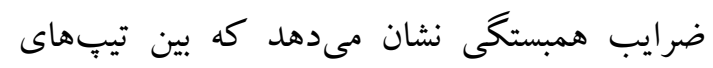

\begin{tabular}{|c|c|c|c|c|c|c|}
\hline \multirow[t]{2}{*}{$\mathbf{R}^{2}$} & \multirow[t]{2}{*}{$\mathbf{R}$} & \multirow[t]{2}{*}{ سطح معنادارى } & \multirow[t]{2}{*}{ t t t t t } & \multicolumn{2}{|c|}{ ضرايب رترسيون } & \multirow[t]{2}{*}{ متغير ييشبين } \\
\hline & & & & استانداردشده & استانداردنشده & \\
\hline \multirow[t]{9}{*}{$\cdot / r V r$} & . $/ \Delta Y Y$ &.$/ \cdot 1$ & $r M / \Delta r$ & & VD/Dr & مقدار ثابت \\
\hline & &.$/ \cdot 1$ & $V / N$ & $\cdot \pi r$ & $1 / \pi 9$ & درون كرايى \\
\hline & & $\cdot 1 \cdot .1$ & $-V / N r$ & $-\cdot / T Y$ & $-1 / \pi 9$ & برون كرايـ \\
\hline & & $\cdot 1 \cdot .1$ & r/A9 &.$/ 19$ & $\cdot / N I$ & شهودى \\
\hline & & $\cdot 1 \cdot \cdot 1$ & $-r / 19$ &.$- / 19$ & $-\cdot / \mathrm{NI}$ & حسى \\
\hline & &.$/ \cdot 1$ & $-9 / 94$ & $-\cdot / 49$ & $-1 / 19$ & عقلانى \\
\hline & & $\cdot 1 \cdot .1$ & 9/9r & $\cdot / 49$ & $1 / 19$ & احساسى \\
\hline & & $.1 \cdot 1$ & $r / Y \Lambda$ & $\cdot / \mathrm{VV}$ & .190 & با ساختار \\
\hline & & $\cdot 1 . \cdot 1$ & $-F / Y \Lambda$ & $-\cdot / / V$ & -.190 & منعطف \\
\hline
\end{tabular}

با توجه به مقادير R مندرج در جدول فوق، تيبّهاى شخصيتى حدود Y درصد ترس از تجرد را تبيين مى كنند كه مقدار معنادارى است.

\begin{tabular}{|c|c|c|c|c|c|c|}
\hline \multirow[t]{2}{*}{$\mathbf{R}^{2}$} & \multirow[t]{2}{*}{$\mathbf{R}$} & \multirow{2}{*}{ معنادارى سطح } & \multirow[t]{2}{*}{ Tاره } & \multicolumn{2}{|c|}{ ضرايب ركرسيون } & \multirow[t]{2}{*}{ متغير بيشبين } \\
\hline & & & & استانداردشده & استانداردنشده & \\
\hline \multirow[t]{6}{*}{$\cdot / 1 \Delta F$} & - &.$/ . \cdot 1$ & IN/AY & & N & مقدار ثابت \\
\hline & &.$/ \cdot \cdot 1$ & $-4 / 90$ & 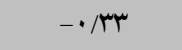 & $-\cdot / 49$ & مهارت درون فردى \\
\hline & & $\cdot / \mathrm{Al}$ & $r / 91$ & $\cdot / 11$ & $\cdot / T V$ & مهارت بين فردى \\
\hline & & $.1 .4 \Delta$ & $-1 / 9 r$ & $-\cdot / 1$ &.$- / 19$ & كنترل استرس \\
\hline & &.$/ . \mu$ & $-Y / \cdot V$ & $-\cdot / / r$ & $-\cdot / 11$ & ساز كارى \\
\hline & &.$/ . r q$ & $1 / 19$ & $\cdot / M r$ & $-\cdot / Y r$ & خلق كلى \\
\hline
\end{tabular}


جدول rا، مؤلفه هاى هوش هيجانى حدود 19 درصد از واريانس ترس از تجرد را تبيين مى كنند كه مقدار معنادارى است.
در اين بخش با استفاده از تكنيك آمارى ركرسيون هم زمان به ييشيينى ترس از تجرد بر اساس مؤلفهاى هوش

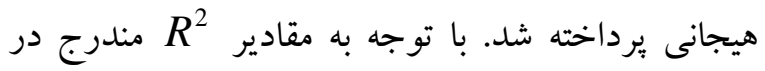

\begin{tabular}{|c|c|c|c|c|c|c|}
\hline \multirow[t]{2}{*}{$\mathbf{R}^{2}$} & \multirow[t]{2}{*}{$\mathbf{R}$} & \multirow{2}{*}{ سطنادارى } & \multirow[t]{2}{*}{ Tاره } & \multicolumn{2}{|c|}{ ضرايب ركر سيون } & \multirow[t]{2}{*}{ متغير ييشبين } \\
\hline & & & & استانداردشده & استانداردنشده & \\
\hline \multirow[t]{5}{*}{$\cdot / \cdot M$} & $\cdot /$ TqV & $\cdot / \cdot \cdot 1$ & $\mathrm{~V} / \mathrm{M}$ & & $r \cdot 191$ & مقدار ثابت \\
\hline & &.$/ \cdot 1 r$ & $r / \Delta r$ & $\cdot / \mathrm{IV}$ & $\cdot / \Delta r$ & سن \\
\hline & &.$/ . k F$ & $-Y / \cdot r$ & $-\cdot / \pi$ & $-1 / \pi q$ & در آمد \\
\hline & & $\cdot / \cdot P V$ & 1/99 & $\cdot / 1$ & r/VQ & مقطع تحصيلى \\
\hline & & $\cdot / 1 \Delta r$ & $1 / 4 \pi$ & .1 .9 & $1 / \mathrm{AM}$ & جنسيت \\
\hline
\end{tabular}

داد كه رابطه بين تيبٍهاى شخصيتى و ترس از تجرد معنادار است. اين يافتها نشان داد كه بين تيبهاى

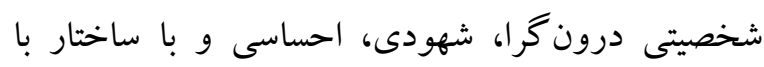
ترس از تجرد رابطه مثبت معنىدار وجود داشته و رابطه

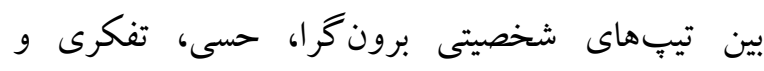
منعطف با ترس از تجرد منفى است. اين يافته با با بان

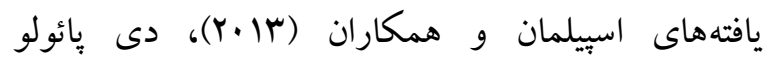
(Y.|F)

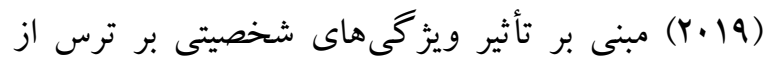
تجرد همسو بود. تيبّهاى شخصيتى جزو صفات بايدار وجود آدمى است كه بر بسيارى از افكار و هيجانات

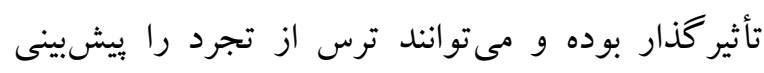
كند (اسبيلمان و همكاران، سا.ب). در تبيين اين يافتها مىتوان كفت در بسيارى از مواقع موفقيت در يافنن شريكك عاشقانه معلول روابط بيرونى و اجتماعى است تا عوامل درونى و ذهنى (بويز و همكاران، 19 +Y)؛ بنابر اين

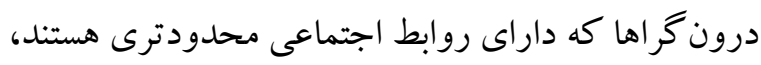
شانس كمترى را براى بيدا كردن شريك مورد نظر خود
به منظور بررسى تأثير متغيرهاى جمعيت شناختى بر ترس از تجرد از مدل رگرسيون جند متغيرى استفاده شد. همانطور كه نتايج جدول F نشان مىدهد عوامل سن (R//IV)

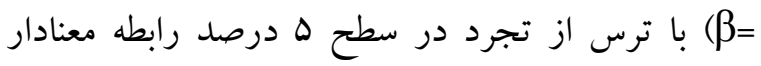
دارند و مثبت بودن ضرايب سن و مقطع تحصيلى درواقع نشان دهنده اين است كه با افزايش اين عوامل، ميزان ترس از تجرد افزايش مىيابد. ضريب منفى در آمد نشان دهنده اين است كه با افزايش در آمد، ميزان ترس از تجرد كاهش مىيابد. رابطه بين جنسيت و ترس از تجرد در سطح ه درصد معنادار نبود. درمجموع متغيرهاى جمعيت شناختى قادر به بيشبينى حدود 9 درصد از واريانس ترس از تجرد بودند.

هدف يثزوش حاضر بيشبينى ترس از تجرد بر اساس تيبٍهاى شخصيتى، هوش هيجانى و متغيرهاى جمعيت شناختى در بين دانشجويان دانشگاه تهران بود. نتايج نشان 
كمكك مى كند تا نسبت به هيجانات منفى خودآكاهى كسب نموده، آن را بذيرفته و به طور مناسبى مديريت كنند (بار-آن، 199V). مؤلفه كنترل استرس تابآورى افراد را در مديريت ترس از تجرد بالا مىبرد؛ همجنين بعد كنترل استرس، فى نفسه در برقرارى روابط بين فردى و رابطه با جنس مخالف تأثير مثبتى داشته و اطرافيان افراد با سطح آرامش و كنترل استرس بالا را به افراد نآرام و فاقد كنترل استرس ترجيح مىدهند. به همين دليل اين افراد نماينده بهترى براى ازدواج خواهند بود و ترس از تجرد كمترى احساس خواهند كرد. مؤلفه ساز گارى نيز توانايىهاى ما را در تنظيم هيجانات، اداره كردن شرايط استرسزا و نحوه برخورد با آن نشان مىدهد. مؤلفه خلق كلى نشاندهنده ميزان خوشبينى و شادمانى نسبت به روابط فعلى و آتى بوده و ترس از تجرد را كاهش مىدهد. يرواضح است كه خوشينى و و شادمانى بهطوركلى با نكرانى دو قطب متضاد هستند (بار-آن،

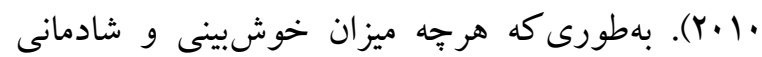
بيشتر باشد، نگرانىهاى فرد در زمينه تجرد و ساير جنبههاى زندكى كمتر خواهد بود. ساير يافتها نشان داد كه مهارتهاى بين فردى به عنوان يكى از مؤلفههاى هوش هيجانى با ترس از تجرد رابطه معنادارى نداشته

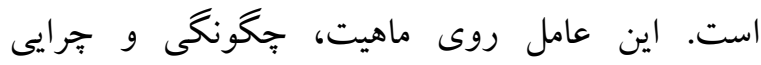
احساسات ديخران متمركز است و به نظر مىرسد كه تمركز بر مهارتها و احساسات خود بهجاى ديخران در تشخيص و كنترل آن كمكك بيشترى به شخص خواهد

فرضيه ديخر اين بزوهش نشان داد كه بين متغيرهاى جمعيت شناختى سن، در آمد و مقطع تحصيلى با ترس از تجرد رابطه معنادار برقرار بوده و بين جنسيت و ترس از
متصور هستند و ترس از تجرد بيشترى تجربه مى كنند. بعد شخصيتى حسى مرتبط با واقعيتها و حضور در لحظه حال است. تأكيد اين دسته از افراد بر (اينجا و اكنون) بوده و كمتر تحت تأثير احساسات متمركز بر وضعيت آينده مانند ترس از مجردماندن قرار مى گيرند (هانيوت و

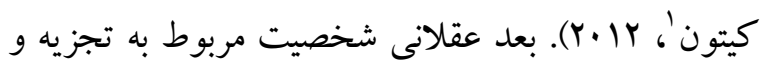
تحليل دقيق وقايع بوده و ناكامى در ازدواج را با دلايل منطقى توجيه مى كنند. در مقابل احساسىها بر اساس ارزش شخصى خود تصميم مى گيرند و در صورت ناتوانى در كنترل هيجانات و ترسهاى ناشى از مجرد ماندن، احتمال ورود به روابط بى كيفيت عاشقانه در بين آنان بيشتر است. تيبّهاى شخصيتى منعطف به مانند ويز گى شخصيتى تجربهيذيرى در رويكرد ينج عاملى نئو، ميزان كشود گى افراد نسبت به تجربيات و روابط جديد را نشان مىدهد (هانيوت و همكاران، Y.|Y). در مقابل تيبّهاى با ساختار، تمايل به برقرارى روابط سازمان يافته

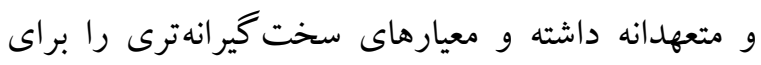
ورود به روابط عاشقانه در نظر مى گيرند؛ بنابراين شانس خود را براى ازدواج كردن كمتر مىدانند و ترس از تجرد بيشترى را تجربه مى كنند. يافته ديخر اين بثروهش نشان داد كه بين هوش هيجانى با ترس از تجرد رابطه منفى معنادار وجود دارد. به طورى كه با افزايش هوش هيجانى، ترس از تجرد كاهش مىيابد. اين رابطه مربوط به ابعاد مهارت هاى درون فردى، كنترل استرس، ساز گارى و خلق كلى بود. يافتهاى اين بخش از يثزوهش با يافتهاى اسبيلمان و همكاران (Y) (Y)،

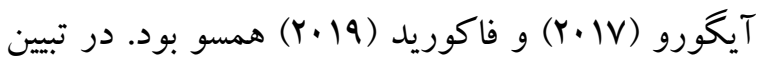
اين يافته مىتوان كفت مهارت هاى درون فردى به افراد

${ }^{1}$ - Honeycutt \& Keaton 
آن را ييشبينى كنند. از محدوديتهاى يُوهش حاضر مى توان به روش نمونه گيرى، محدود بودن جامعه آمارى به دانشجويان دانشگاه تهران و استفاده از شيوه آنلاين براى توزيع برسشنامهها اشاره كرد كه مىبايست در تعميم. نتايج جانب احتياط رعايت شود. به يزوهشخران بيشنهاد مى گردد به سنجش ترس از تجرد در بين ساير گروهها نيز يرداخته و بيامدهاى ترس از تجرد را بر جنبههاى مختلف بر برن

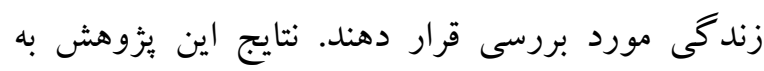
مشاوران و متخصصان حوزه سلامت روان كمك مى كند تا در مشاورههاى فردى و ييش از ازدواج به نقش ترس از تجرد در انتخابها و ترجيحات افراد توجه داشته باشند و متناسب با آن راهكارهاى عملى و درمانى مناسبى اتخاذ

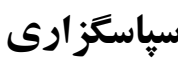

يثزوششران از كليه دانشجويان دانشخاه تهران كه حاضر

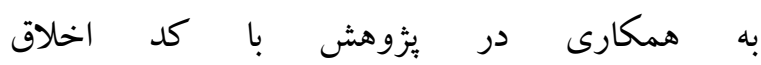
IR.UT.PSYEDU.REC.1399.027

$$
\text { تشكر و قدردانى را دارند. }
$$

\section{References}

Afzali Grouh S. (2017). Investigating the factors and consequences of marriage survival in girls (qualitative research). $\mathrm{PhD}$ Thesis, Faculty of Humanities, Kharazmi University. (InPersian)

Aigoro MH. (2018). The Impact Relationship Factors Have on Single Mothers' Fear of Being Single and Dependency(Doctoral dissertation, Capella University).

Bar-On R. (1997). Development of the Bar-On EQ-I: A measure of emotional and social intelligence. Paper presented at the 105th Annual Convention of the American Psychological Association, Chicago, USA.
تجرد رابطه معنادارى يافت نشد. در اين راستا جايگاه مطلوب اجتماعى و اقتصادى (مانند شغل، در آمد، مقطع تحصيلى) زمينه را براى كسب هويت اجتماعى و فردى مستقل فراهم كرده و مشكلات كمترى در باب مجرد بودن ايجاد مى كند (بادجن '، 19 (Y). در تبيين اين يافتها مىتوان كفت كه بالا رفتن سن با افزايش فشارهاى درونى (افكار و هيجانات منفى) و فشارهاى بيرونى (جامعه و اطرافيان) ناشى از مجرد بودن همراه است

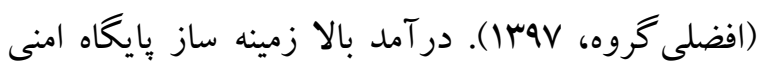
براى استقلال و آزادى افراد فراهم كرده و نخرانى كمترى بابت مجرد بودن ايجاد مى كند (شهانواز و

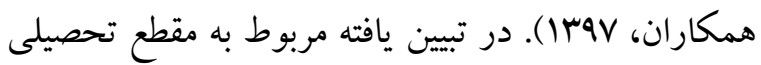
مى توان كفت كه ورود به مقاطع تحصيلى بالاتر با افزايش سطح انتظارات و فشارهاى بيرونى براى ازدواج از يكسو و بالا رفتن سن از سوى ديخر همراه است كه ترس از تجرد را تحت تأثير قرار مىدهد. يافته ديخر بثزوهش نشان داد تفاوت معنادارى بين دختران و بِران ازلحاظ ميزان ترس از تجرد وجود نداشت كه با يافتهاى فونيسكا و همكاران (Y.IV) همسو نبود. به نظر مىرسد تحولات اخير جامعه ايرانى و حركت به سمت بالا رفتن استقلال و بايخاه امن اجتماعى و اقتصادى، كليشههاى جنسيتى در مورد دختران مجرد را كاهش داده و اين اختلاف در ميزان ترس از تجرد نيز معنادار نبوده است.

\section{نتيجه كيرى}

به طوركلى، نتايج حاصل از اين ئوهش نشان داد كه تيبّهاى شخصيتى، هوش هيجانى و متغيرهاى جمعيت شناختى با ترس از تجرد رابطه معنادارى داشته و مىتوانند

\footnotetext{
1. Budgeon
} 
Bar-On R. (2010). Emotional intelligence: An integral part of positive psychology. South African Journal of Psychology, 40(1), 54-62.

Bay-Cheng LY, Goodkind SA. (2016). Sex and the single (neoliberal) girl: Perspectives on being single among socioeconomically diverse young women. Sex Roles, 74(5-6), 181-194.

Berscheid ES, Regan PC. (2016). The psychology of interpersonal relationships. Psychology Press.

Bowlby J. (1982). Attachment and loss: retrospect and prospect. American journal of Orthopsychiatry, 52(4), 664678.

Boyce CJ, Wood AM, Ferguson E. (2016). For better or for worse: The moderating effects of personality on the marriage-life satisfaction link. Personality and Individual Differences, 97, 61-66.

Budgeon S. (2016). The 'problem'with single women: Choice, accountability and social change. Journal of Social and Personal Relationships, 33(3), 401-418.

CorrettiCA. (2019). An Investigation Into the Effects of Cross-Sex Friendships on Heterosexual Romantic Relationship Dynamics (Doctoral dissertation).

Dehshiri G. (2003). Standardization of Bar-An Emotional Interest Questionnaire to evaluate different aspects of emotional intelligence of Tehran University students. Master Thesis in Psychology, Allameh Tabatabai Faculty. (In Persian)

DePaulo B. (2014). A singles studies perspective on mount marriage. Psychological Inquiry, 25(1), 64-68.

Fakorede MB. (2019). Emotional Intelligence and Romantic Relationship Satisfaction(Doctoral dissertation, Dublin, National College of Ireland).

Fonseca PND,Gouveia VV, dos Santos JLF, Couto RN, Coelho GDH. (2017). Psychometric and validity evidence of the Fear of Being Single Scale. Trends in Psychology, 25(4), 15111521.

Furnham A. (1996). The big five versus the big four: the relationship between the Myers-Briggs Type Indicator (MBTI) and NEO-PI five factor model of personality. Personality and Individual Differences, 21(2), 303-307.

Ghafariyan Mabhut E. (2015). The process of raising the age of marriage in girls on the verge of definite celibacy. Master Thesis, Faculty of Humanities, Ferdowsi University of Mashhad. (In Persian)

Harris K, Vazire S. (2016). On friendship development and the Big Five personality traits. Social and Personality Psychology Compass, 10(11), 647-667.

Honeycutt JM, Keaton SA. (2012). Imagined interactions and personality preferences as predictors of relationship quality. Imagination, Cognition and Personality, 32(1), 3-21.

Khodabakhsh Pirkalani R, Amani F, Raiisi F, Hajkaram A. (2020). Predicting adolescents social skills based on their parents emotional intelligence. Shenakht Journal of Psychology and Psychiatry, 7(1), 141-152. (In Persian)

Mahmoudian Dehkordi A. (2007). Standardization and determining the validity and reliability of Myers-Briggs type among the employees of shahrekord departments, M.Sc. Thesis, University of Isfahan, Faculty of psychology and educational sciences. (In Persian)

Malouff JM, Schutte NS, Thorsteinsson EB. (2014). Trait emotional intelligence and romantic relationship satisfaction: A meta-analysis. The American Journal of Family Therapy, 42(1), 53-66.

Paetzold RL, Rholes WS, Kohn JL. (2015). Disorganized attachment in adulthood: Theory, measurement, and implications for romantic relationships. Review of General Psychology, 19(2), 146-156.

Shahanavaz S, Azam Azadeh M. (2018). A Metasynthesis of Singleness Studies in Iran. Women's Studies Sociological and Psychological, 16(4), 43-78. (InPersian)

Spielmann SS, Mac Donald G, Joel S, Impett EA. (2016). Longing for ex- partners out of fear of being single. Joumal of personality, 84(6), 799808.

Spielmann SS, MacDonald G, Maxwell JA, Joel S, Peragine D, Muise A, Impett EA. (2013). 
Settling for less out of fear of being single. Joumal of personality and social psychology, 105(6), 1049.

Spielmann SS, Maxwell JA, Mac Donald G, Peragine D, Impett EA. (2020). The predictive effects of fear of being single on physical attractiveness and less selective partner selection strategies. Journal of Social and Personal Relationships, 37(1), 100-123.

Timmermans E, Coenen L, Van Den Bulck J. (2019). The Bridget Jones effect: The relationship between exposure to romantic media contents and fear of being single among emerging adults. Psychology of Popular Media Culture, 8(2), 159-169. 